\title{
RONA AWAL LINGKUNGAN PERAIRAN MUARA SATUI UNTUK KESESUAIAN AREA PELABUHAN (STUDI KASUS PENGEMBANGAN KAWASAN PELABUHAN)
}

\section{BASELINE STUDY OF ENVIRONMENTAL CONDITION OF SATUI ESTUARY FOR PORT SUITABILITY ASSESSMENT (A CASE STUDY OF INTEGRATED PORT DEVELOPMENT)}

\author{
Johan Risandi, Vivi Yovita Indriasari, Rudhy Akhwady \& Agus Sufyan \\ Pusat Riset Kelautan, Badan Riset dan Sumber Daya Manusia Kelautan dan Perikanan \\ e-mail : johanrisandi@kkp.go.id
}

Diterima tanggal: 31 Maret 2021 ; diterima setelah perbaikan: 23 Agustus 2021 ; Disetujui tanggal: 25 Agustus 2021

\begin{abstract}
ABSTRAK
Rencana pengembangan suatu kawasan estuari untuk pelabuhan perlu memperhitungkan kondisi awal lingkungan karena daerah pelabuhan sangat rentan terhadap cemaran lingkungan akibat beragam aktivitas yang dilakukan. Studi ini bertujuan untuk mengetahui kualitas lingkungan perairan Muara Satui, Tanah Bumbu, Kalimantan Selatan yang potensial untuk dikembangkan sebagai kawasan kegiatan pelabuhan terpadu. Kualitas fisika, kimia dan biologi air hasil pengamatan dibandingkan dengan standar baku mutu air laut yang ditetapkan oleh Kementrian Lingkungan Hidup Indonesia. Selanjutnya, hasil pengamatan dianalisa lebih lanjut dengan Indeks Kualitas Air (IKA) untuk mengetahui gambaran umum kualitas perairan. Hasil analisa menunjukkan perairan muara Satui mempunyai kualitas perairan yang sangat bagus dengan parameter fisika (seperti salinitas 14 ppt, suhu $28^{\circ} \mathrm{C}$ ), kimia (seperti DO 4,9 mg/l, dan BOD 5,41 mg/l), dan biologi (yaitu plankton dengan Indeks Dominansi Simpson 0,20-0,27) masih dalam kisaran standar baku mutu air laut untuk pelabuhan. Dari nilai IKA dengan kisaran 0,001 sampai 6,5 untuk berbagai parameter yang dianalisa, dapat disimpulkan bahwa perairan masih dalam kondisi yang sangat bagus. Hal tersebut mengindikasikan perairan tersebut layak untuk dijadikan kawasan pengembangan pelabuhan.
\end{abstract}

Kata kunci: Penilaian kesesuaian, pelabuhan, kualitas air, Muara Satui.

\begin{abstract}
A plan on port development at an estuary needs to consider its initial environmental condition because of the vulnerability of an estuary to contaminations due to port activities. The study was aimed to assess the water quality of Satui estuary, Tanah Bumbu, South Kalimantan that is prospective to be developed as an integrated port area. Physical, chemical and biological parameters of Satui estuary obtained from a field measurement were compared to water quality standard issued by the Indonesian Ministry of Environment. The results of the observation were further analysed using Water Quality Index to assess the general quality of the estuary. The results showed Satui estuary was in general considered to have a very good sea water quality, in which the tested physical (e.g., salinitiy of $14 \mathrm{ppt}$ and temperature of $28^{\circ} \mathrm{C}$, chemical (e.g., DO 4,9 mg/l, and BOD 5,41 $\mathrm{mg} / \mathrm{l}$ ) and biological (i.e., plankton with the Simpson Dominance Index of 0.2-0.27) parameters were still within a range of the water quality standard for port activity purposes. Moreover, the WQI results with ranges of 0,001-6.5 for the analysed parameters showed the condition of the area was very good. Those indicated that the estuary was suitable for an integrated port development.
\end{abstract}

Keywords: suitability assessment, port, water quality, Satui estuary.

Rona Awal Lingkungan Perairan Muara Satui untuk Kesesuaian Area Pelabuhan (Studi Kasus Pengembangan Kawasan Pelabuhan) - Johan Risandi, Vivi Yovita Indriasari, Rudhy Akhwady \& Agus Sufyan 


\section{PENDAHULUAN}

Peningkatan jumlah penduduk selalu diimbangi dengan peningkatan pemanfaatan sumber daya alam untuk pemenuhan kebutuhannya. Aktivitas ini berkolerasi positif dengan pertumbuhan ekonomi, dimana kemajuan pertumbuhan ekonomi akan diikuti pertambahan pemanfaatan sumberdaya alam untuk proses produksi. Aktivitas manusia seringkali menghasilkan residu berupa limbah dan cemaran yang menimbulkan tekanan terhadap lingkungan (environmental stress). Kajian lingkungan tersebut diperlukan sebagai upaya evaluasi untuk pelestarian fungsi lingkungan dan pengendalian terhadap usaha maupun kegiatan yang berpotensi menghasilkan cemaran yang menimbulkan kerusakan lingkungan hidup (Seda, 2006).

Pelabuhan merupakan jembatan penghubung vital kegiatan transportasi di Indonesia yang terdiri dari ribuan kepulauan. Pelabuhan berkontribusi pada aktivitas keluar masuknya komoditas dan penumpang yang menjadi pendapatan negara melalui pajak. Selain itu, pelabuhan mempunyai peranan vital pada pertumbuhan ekonomi, misalnya pada produktivitas tenaga kerja dan nilai konsumsi di sekitar kawasan Pelabuhan (Ignasiak-Szulc et al, 2018). Sebagaimana kegiatan ekonomi yang lain, pengembangan suatu kawasan pelabuhan juga perlu memperhatikan kondisi lingkungan karena besarnya potensi untuk merubah kondisi lingkungan baik pada saat pembangunan maupun saat pelabuhan tersebut beroperasi (Darbra et $a l$, 2005). Operasional pelabuhan seperti bongkar muat komoditas dan naik turun penumpang ataupun aktivitas kapal dan kegiatan penunjang lainnya berpotensi menghasilkan cemaran yang menurunkan kualitas lingkungan di sekitar pelabuhan, khususnya kondisi fisik, kimia dan biologi yang sangat cepat berubah karena aktifitas manusia. Oleh karena itu sebelum adanya pengembangan pelabuhan, diperlukan kajian kualitas lingkungan untuk mengetahui kondisi awal di daerah yang potensial untuk kegiatan tersebut (Wooldridge et al, 1999).

Satui adalah salah satu kecamatan di Kabupaten Tanah Bumbu, Kalimantan Selatan yang terkenal sebagai salah satu pusat produksi batubara di Indonesia (Gambar 1). Batubara Satui memiliki kualitas tinggi yang utamanya diperoleh dari tambang Senakin di terusan bagian bawah dari Tanjung Pembentukan, di bagian tenggara lereng Pegunungan Meratus. Selain itu, tambang di Satui terbentang sepanjang kira-kira 40 $\mathrm{km}$ dari timur laut sampai barat daya dengan total produksi lebih dari 2,5 milyar metrik ton (MT) tiap tahun (http://www.tanahbumbukab.go.id/). Kecamatan Satui juga merupakan sentra produksi sawit di Kabupaten Tanah Bumbu dengan produksi mencapai 239.904 ton pada tahun 2019 (BPS, 2019). Pada kecamatan tersebut, terdapat sungai Satui yang berkelok-kelok (meander) yang membentang sepanjang $73 \mathrm{~km}$ dan lebar sungai \pm 120 meter dengan muara sungai menghadap Laut Jawa (Gambar 1). Kondisi tersebut menjadikan perairan Satui terlindung dari gelombang yang dapat mengganggu kegiatan bongkar muat kapal. Saat ini di muara sungai Satui terdapat kegiatan kepelabuhanan (Gambar 2), baik kapal penumpang maupun transportasi air untuk hasil tambang berupa batubara dan bongkar muat curah kering dan basah lainnya. Terdapat belasan terminal khusus (Tersus) batubara yang beroperasi di sepanjang sungai Satui untuk melayani kebutuhan transportasi batubara hasil tambang menuju pengguna. Setiap hari, puluhan tongkang berlayar melewati muara Satui selama 24 jam. Dari kondisi tersebut, muara perairan Satui sangat potensial untuk dikembangkan lebih lanjut sebagai kawasan pelabuhan terpadu, akan tetapi dari banyaknya aktivitas di sekitar sungai yang sudah berlangsung lama, maka muara sungai Satui diindikasikan mempunyai beban lingkungan yang cukup besar. Beban tersebut akan sangat mungkin bertambah jika kawasan pelabuhan terpadu diwujudkan.

Penelitian ini bertujuan untuk mengetahui kualitas lingkungan perairan Muara Satui, Tanah Bumbu, Kalimantan Selatan yang berpotensi untuk dikembangkan sebagai kawasan kegiatan pelabuhan terpadu yang terintegrasi dengan industri khususnya bidang pertambangan dan pertanian. Studi kualitas lingkungan dilakukan melalui pengambilan data lapangan parameter fisika, biologi dan kimia perairan dan membandingkan hasil analisanya dengan standar baku mutu lingkungan.

\section{BAHAN DAN METODE}

Survei pengukuran di sekitar muara Satui, Kabupaten Tanah Bumbu, Propinsi Kalimantan Selatan telah dilakukan pada 5 Juli 2014. Pada studi ini, terdapat dua stasiun pengamatan yang terletak di muara sungai pada koordinat $-3,807632{ }^{\circ} \mathrm{S} ; 115,484898{ }^{\circ} \mathrm{E}$ (ST1) dan $-3,811236^{\circ} \mathrm{S} ; 115,478265^{\circ} \mathrm{E}$ (ST2), seperti ditunjukkan pada Gambar 1.

Pemilihan stasiun dilakukan secara sengaja (purposive sampling) (Sugiyono. 2016) dengan asumsi bahwa kedua stasiun tersebut mewakili kondisi perairan muara 


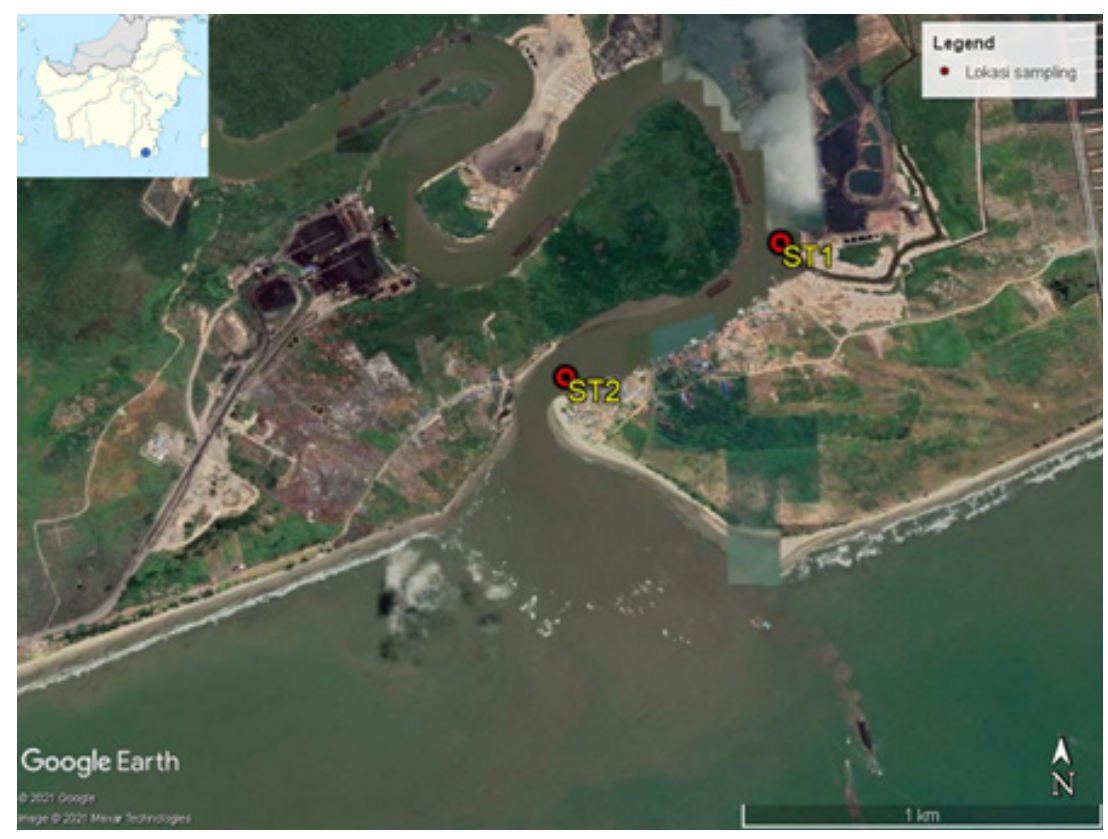

Gambar 1. Lokasi pengamatan kualitas air di muara Satui (titik-titik merah, ST1 and ST2). Insert adalah lokasi penelitian di pulau Kalimantan (Sumber: Google Earth, 2021)

Figure 1. Location of water quality observations (red dots). Insert is the location of study in Kalimantan (Source: Google Earth, 2021)

sungai Satui. Stasiun (ST1) terletak di antara beberapa terminal khusus (tersus) batubara, sedangkan Stasiun (ST2) berada di daerah dekat muara dan pelabuhan penumpang (Gambar 1). Pada tiap lokasi, dilakukan pengambilan 1 sampel tiap parameter. Pengambilan sampel di luar muara (laut lepas) tidak dilakukan karena padatnya lalu lintas tongkang dan kapal. Pada kedua stasiun, dilakukan pengamatan lapangan (insitu) dan laboratorium untuk parameter fisik, kimia dan biologi (plankton) perairan yang dianggap dapat terdampak oleh kegiatan kepelabuhanan di wilayah tersebut. Pengambilan sampel air untuk analisa sulfida, fenol, minyak dan lemak, serta logam berat hanya dilakukan pada ST 1 dengan asumsi kedua titik sampling mempunyai karakteristik perairan yang hampir sama karena dekatnya kedua lokasi $( \pm 1 \mathrm{~km})$. Analisa in situ, yaitu salinitas, suhu, kecerahan dan kebauan, dilakukan dengan menggunakan beberapa alat bantu seperti disajikan pada Tabel 1, sedangkan analisa laboratorium untuk sampel air (setelah sampel air diawetkan dengan pendinginan pada suhu $4{ }^{\circ} \mathrm{C}$ untuk kimia air dan formalin untuk plankton) dilakukan dengan beberapa alat seperti yang disebutkan pada Tabel 1 di Laboratorium Kualitas Air Fakultas Perikanan dan Kelautan, Universitas Lambung Mangkurat dan Laboratorium Pengujian Balai Pengembangan Teknologi dan Konstruksi Banjarmasin. Parameter lingkungan yang diamati disajikan pada Tabel 1 .
Sampel plankton dianalisa dengan mikroskop untuk mengetahui beberapa parameter berikut. Indeks keanekaragaman Shannon-Wiener (H') digunakan untuk mengetahui kondisi variasi jenis plankton yang ada di suatu daerah dimana nilai $\mathrm{H}^{\prime}<1$ adalah kategori keanekaragaman rendah; $1<\mathrm{H}^{\prime}<3$ kategori keanekaragaman sedang dan $\mathrm{H}^{\prime}>3$ kategori keanekaragaman tinggi. Selain itu, analisa indeks keseragaman (E) dilakukan dimana E berkisar antara $0-1$. $E=0$ berarti keseragaman antara spesies rendah sehingga kekayaan individu yang dimiliki masingmasing spesies sangat jauh berbeda. Nilai $E=1$ berarti keseragaman antar spesies relatif merata atau relatif sama. Analisa indeks keragaman (D') yang merupakan proporsi antara luas bidang dasar yang ditempati oleh spesies tumbuhan dengan luas total habitat dibagi menjadi 3 kategori yaitu $D^{\prime}=0-0,30$ merupakan Dominansi Rendah, D' $=0,31-0,60$ berarti Dominansi Sedang dan D' $=0,61-1,0$ adalah Dominansi Tinggi (Odum, 1993).

Hasil pengamatan in situ dan laboratorium untuk parameter fisika dan kimia dianalisa secara deskriptif, kemudian dibandingkan dengan standar baku mutu lingkungan untuk pelabuhan berdasar pada Keputusan Menteri Negara Lingkungan Hidup No. 51 tahun 2004 tentang Baku Mutu Air Laut untuk Perairan Pelabuhan (Tabel 2). Kondisi plankton suatu perairan dapat digunakan sebagai indikator biologi dimana 


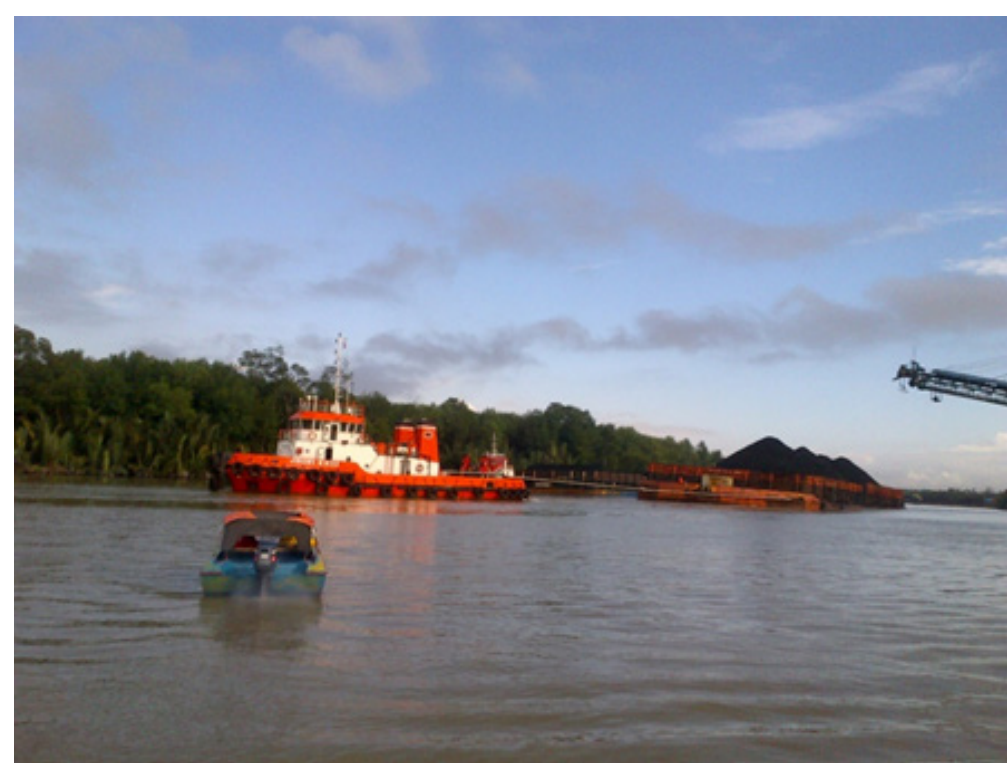

Gambar 2. Kegiatan transportasi air di muara sungai Satui.

Figure 2. Water transportation activities at Satui estuary.

Tabel 1. Parameter lingkungan yang diamati dan metode analisanya Table 1. Observed environmental parameters and the analysis methods

\begin{tabular}{lll}
\hline No & Parameter & Alat yang digunakan \\
\hline & Fisika & \\
1 & Suhu & Refraktometer (in situ) \\
2 & Salinitas & DO meter (in situ) \\
3 & Kecerahan & Sechi-disk (In situ) \\
4 & Kebauan & (In situ) \\
\hline & Kimia & \\
5 & DO & DO meter (in situ) \\
6 & BOD & Winkler/tirtrasi iodometeri (lab) \\
7 & pH & pH meter (lab) \\
8 & Total amonia & Spektofotometer (lab) \\
9 & Sulfida & Spektofotometer (lab) \\
10 & Fenol & Spektofotometer (lab) \\
11 & Minyak dan lemak & Spektofotometer (lab) \\
12 & Logam berat (Raksa, & Spektofotometer (lab) \\
& Cadmium, Tembaga, & \\
& Timbal, Seng) & \\
\hline & Biologi & Mikroskop \\
\hline
\end{tabular}

keberadaan atau tingkah-lakunya kemungkinan berkorelasi sangat erat dengan kondisi lingkungan tertentu yang dapat digunakaan sebagai petunjuk atau uji kuantitatif (Ellenberg. 1991). Untuk mengetahui tingkat pencemaran pada suatu perairan, digunakan parameter H' dan D' seperti disajikan pada Tabel 3.

Untuk mengetahui gambaran umum kondisi fisika dan kimia perairan muara Satui, dilakukan integrasi hasil analisa parameter-parameter yang diuji (Tabel 2) menggunakan Indeks Kualitas Air (IKA) atau Water Qualilty Index (WQI), berdasar metode yang dikembangkan oleh Brown et al (1972), dimana:

$$
W Q I=\sum_{i=1}^{n} w_{i} q_{i} / \sum_{i=1}^{n} w i
$$


Tabel 2. Standar baku mutu lingkungan untuk parameter-parameter terpilih Table 2. Environmental quality standards for the selected parameters

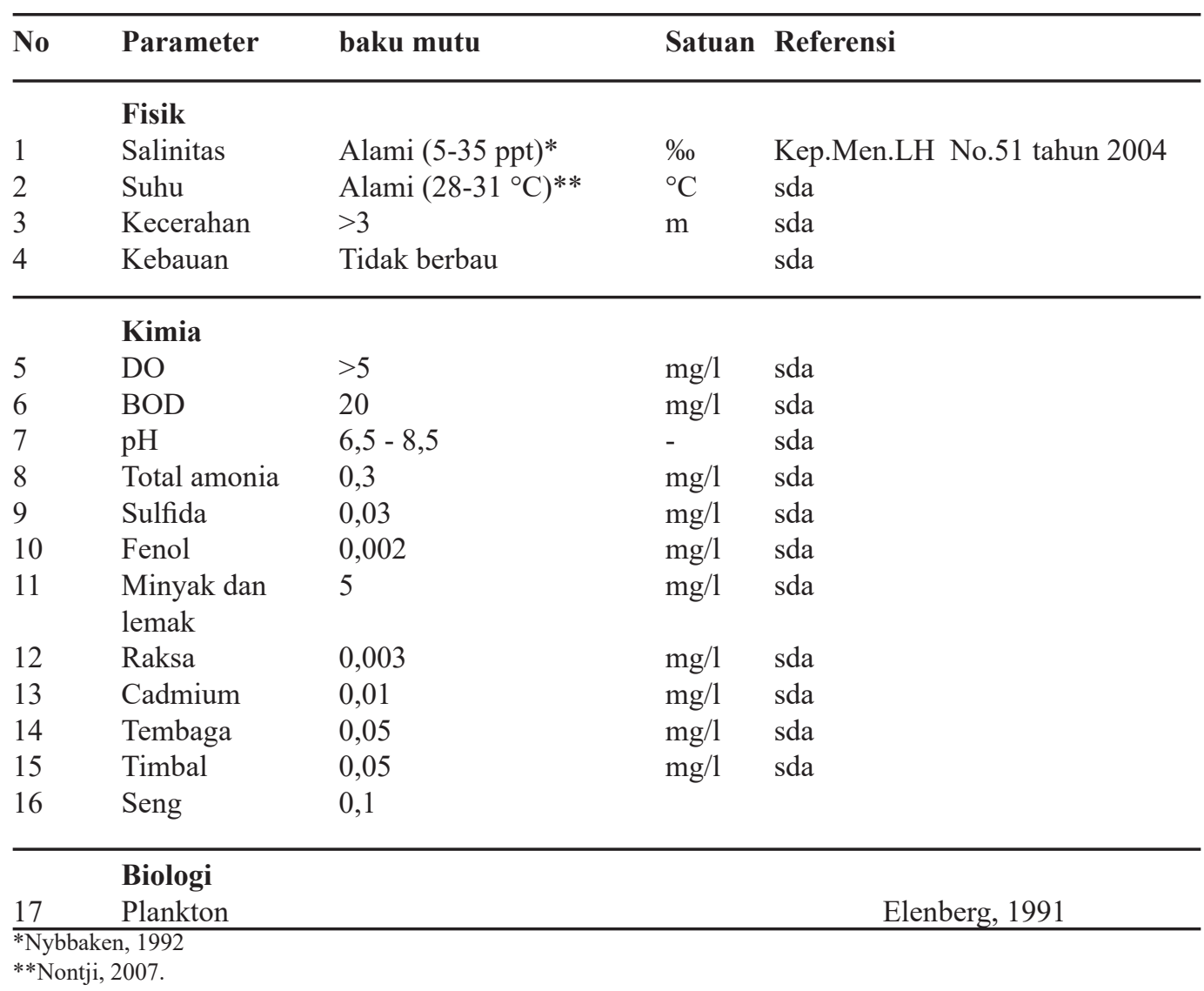

Tabel 3. Tingkat pencemaran perairan berdasar Indeks Diversitas (H') dan Indeks Dominansi (D) plankton Table 3. The level of water pollution based on plankton Diversity Index ( $\left.H^{\prime}\right)$ and Dominance Index (D)

\begin{tabular}{llllll}
\hline Parameter & \multicolumn{5}{l}{ Kriteria } \\
Indeks Diversitas (H') & Belum tercemar & Tercemar ringan & Tercemar sedang Tercemar berat \\
\cline { 2 - 6 } & $>2,0$ & $1,6-2,0$ & $1,0-1,5$ & $<1,0$ & \\
\hline Indeks Dominansi (D) & Sangat Jelek & Jelek & Sedang & Baik & Sangat Baik \\
& $\leq 0,07$ & $0,08-0,15$ & $0,16-0,23$ & $0,24-0,31$ & $\geq 0,32$ \\
\hline
\end{tabular}

Sumber: Odum, 1993; Perwira dan Ulinuha, 2014; Protasov et al, 2019

wi adalah bobot relatif dari parameter ke i yang diteliti dan qi nilai sub-indeks yang dihitung dengan

$$
q_{i}=100\left[\left(x_{i}-x a_{i}\right) /\left(x b_{i}-x a_{i}\right)\right]
$$

dengan xi adalah konsentrasi dari parameter ke i, xai adalah nilai baku mutu parameter ke i, dan xbi adalah nilai konsentrasi parameter ke i di air murni (biasanya dianggap 0 , kecuali $\mathrm{pH} 7$ dan salinitas air laut $30 \mathrm{ppt}$ ). Kondisi suatu perairan berdasar IKA dikelompokkan menjadi lima yaitu sangat bagus, bagus, buruk, sangat buruk dan tidak layak (Tabel 4), lebih detail baca Sener et al., 2017 dan Tyagi et al., 2013.
Tabel 3. Tingkat pencemaran perairan berdasar Indeks Diversitas (H') dan Indeks Dominansi (D) plankton Table 3. The level of water pollution based on plankton Diversity Index ( $\left.H^{\prime}\right)$ and Dominance Index (D)

\begin{tabular}{ll} 
Indeks Kualitas Air & Status Kualitas Air \\
\hline $0-25$ & Sangat bagus \\
$26-50$ & Bagus \\
$51-75$ & Buruk \\
$76-100$ & Sangat buruk \\
$>100$ & Tidak layak \\
\hline
\end{tabular}




\section{HASIL DAN PEMBAHASAN}

\section{Kualitas fisika air}

Hasil analisa sampling pada kedua stasiun menunjukkan salinitas muara seragam yaitu 14 ppt (Tabel 5), sehingga perairan muara Satui dapat dikategorikan estuari (535 ppt) (Nybakken, 1992). Rendahnya salinitas yang tercatat di muara dibandingkan salinitas alami air laut (30-35 ppt), walaupun jarak stasiun sampling relatif dekat dengan laut lepas $(<1 \mathrm{~km}$, Gambar 1), menunjukkan besarnya pengaruh aliran air tawar dari sungai dan juga dimungkinkan karena pengambilan data dilakukan ketika kondisi surut, sehingga air sungai lebih dominan mengalir menuju laut.

Suhu perairan pada lokasi studi pada saat sampling (siang hari) berada pada kisaran suhu perairan tropis (Tabel 5) yang aman untuk biota yaitu $28-31^{\circ} \mathrm{C}$ (Nontji, 2007). Sama halnya dengan salinitas, suhu perairan yang terlalu tinggi dapat menyebabkan penurunan kadar oksigen terlarut yang mengganggu kehidupan organisme perairan (Saeni, 1997). Survey in situ dengan sechi-disk menunjukkan perairan muara Satui mempunyai kecerahan kurang dari 3 m (Tabel 5) yang mengindikasikan terjadinya proses sedimentasi yang menyebabkan kekeruhan yang bisa diakibatkan oleh tidal asimetri, sirkulasi di daerah estuary yang bisa di akibatkan proses stratifikasi (Burchard \& Baumert, 1998; Jay \& Musiak, 1994; Prandle, 2004). Air di perairan Tersus tidak berbau karena tidak ada kegiatan di sekitar lokasi, baik industri maupun masyarakat, yang dapat memproduksi limbah.

\section{Kualitas kimia perairan}

Hasil analisa kualitas kimia air (Tabel 6) menunjukkan bahwa semua parameter uji berada di bawah ambang baku mutu yang ditetapkan. Nilai Dissolved Oxygen (DO) perairan Satui berada pada kisaran 5 ppt yang mengindikasikan perairan tersebut dalam kondisi yang bagus. Semakin tinggi konsentrasi DO, maka semakin bagus kondisi perairan. Pada kondisi DO yang tinggi, oksigen terlarut yang berperan dalam proses oksidasi serta reduksi bahan organik dan anorganik dengan hasil akhirnya adalah nutrient sebagai indikasi kesuburan perairan (Anggriawan, 2013). Biological oxygen Demand (BOD) adalah banyaknya oksigen yang diperlukan oleh organisme pada saat pemecahan bahan organik. Perairan yang tercemar mempunyai kandungan DO yang rendah, sebagai kompensasinya nilai BOD akan tinggi. Nilai BOD dapat digunakan untuk mengestimasi jumlah oksigen terlarut yang dibutuhkan oleh suatu perairan untuk menormalkan limbah organik secara biologis (Jouanneau et al., 2014). Hasil sampling menunjukkan BOD pada Stasiun 2 sedikit lebih tinggi dibanding dengan Stasiun 1 (Tabel 6). Nilai BOD pada perairan muara Satui masih di bawah ambang batas yang ditetapkan oleh Kementerian Lingkungan Hidup tahun 2004. Hal tersebut mengindikasikan sedikitnya cemaran organik yang bisa menurunkan kualitas perairan di lokasi

Tabel 5. Parameter lingkungan yang diamati dan metode analisanya

Table 5. Observed environmental parameters and the analysis methods

\begin{tabular}{llllll}
\hline No & Parameter & Stasiun 1 & Stasiun 2 & Baku mutu & Keterangan \\
\hline 1 & Salinitas & 14 & 14 & Alami $(5-35 \mathrm{ppt}) \mathrm{ppt}$ \\
2 & Suhu & 28 & 28 & Alami $\left(28-31^{\circ} \mathrm{C}\right){ }^{\circ} \mathrm{C}$ \\
3 & Kecerahan & 2 & 2 & $>3$ & $\mathrm{~m}$ \\
4 & Kebauan & Tidak & Tidak & Tidak berbau & - \\
\hline
\end{tabular}

Tabel 6. Hasil uji kualitas kimia air

Table 6. Result of water quality (chemical parameters)

\begin{tabular}{llllll}
\hline No & Parameter & Stasiun 1 & Stasiun 2 & Baku mutu & Keterangan \\
\hline 1 & DO & 4,9 & 5 & $>5$ & $\mathrm{mg} / \mathrm{l}$ \\
2 & BOD & 5,41 & 7,21 & $<20$ & $\mathrm{mg} / \mathrm{l}$ \\
3 & $\mathrm{pH}$ & 6,92 & 6,98 & $6,5-8,5$ & - \\
4 & Total amonia & 0,103 & 0,104 & 0,3 & $\mathrm{mg} / \mathrm{l}$ \\
5 & Sulfida & $<0,01$ & - & 0,03 & $\mathrm{mg} / \mathrm{l}$ \\
6 & Fenol & $<0,005$ & - & 0,002 & $\mathrm{mg} / \mathrm{m} / 1$ \\
7 & Minyak & $<1$ & - & 5 & \\
\hline
\end{tabular}


(Novotny \& Olem, 1994).

Perairan di lokasi studi mempunyai $\mathrm{pH}$ normal dikisaran 7 dan kandungan sulfida di bawah 0,03 mg/l. Nilai $\mathrm{pH}$ dan sulfida tersebut masih di bawah batas yang ditetapkan oleh Kementerian Negara Lingkungan Hidup. Nilai pH menunjukkan konsentrasi ion hidrogen dalam yang dapat berubah ketika limbah industri atau rumah tangga masuk dan mencemari perairan (Wardhana, 2004), sedangkan kandungan sulfida menunjukkan adanya reaksi yang belum sempurna dari bahan organik yang mengandung sulfur akibat kondisi perairan yang anaerob (Sa'diyah et al., 2018).

Walaupun $\mathrm{pH}$ dan kandungan sulfida pada perairan Satui berada pada kondisi yang baik, perlu diwaspadai penurunan $\mathrm{pH}$ (air menjadi asam) dan kenaikan kandungan sulfida karena menurut Sayoga (2007) dalam Marganingrum \& Noviardi (2010), pada lingkungan tambang batubara seperti pada lokasi studi, perubahan $\mathrm{pH}$ (menjadi lebih asam) dimungkinkan oleh adanya cemaran dari Air Asam Tambang (AAT) atau Acid Mine Drainage (ACM) yang terbentuk sebagai hasil oksidasi mineral sulfida tertentu yang terkandung dalam batuan oleh oksigen di udara pada lingkungan perairan.

Parameter kimia lain yaitu Total ammonia, Sulfida, Fenol serta minyak dan lemak pada perairan muara Satui masih di bawah ambang batas baku mutu yang ditentukan. Unsur nitrogen pada total ammonia merupakan element penting bagi pertumbuhan fitoplankton yang berperan dalam kesuburan perairan akan tetapi, perairan yang mempunyai total ammonia di atas ambang batas baku mutu lingkungan akan dapat membahayakan biota yang hidup di air (Li et al, 2014). Senyawa fenol adalah senyawa alkohol aromatik yang berupa padat atau cair, yang utamanya dihasilkan pada industri migas, farmasi dan resin. Fenol bersifat korosif, toksik, karsinogenik dan mutagenik yang berbahaya bagi lingkungan, (Sivasubramanian \& Namasivayam, 2015). Minyak dan lemak terdapat di dalam air limbah yang merupakan produk rumah tangga dan industri. Pada kawasan pelabuhan, kedua zat tersebut bisa berasal dari kapal atau alat berat yang ada di darat. Minyak dan lemak membentuk ester dan alkohol. Lemak tergolong pada bahan organik yang tetap dan tidak mudah untuk diuraikan oleh bakteri. Terbentuknya emulsi air dalam minyak akan membuat lapisan yang menutupi permukaan air dan dapat merugikan, karena penetrasi sinar matahari ke dalam air berkurang serta lapisan minyak menghambat pengambilan oksigen dari udara menurun (Eljaiek-Urzola et al, 2019).

Pada studi ini, dilakukan uji kadar lima logam berat penting di Muara Satui (Tabel 7) dimana konsentrasi logam berat tersebut merupakan materi yang sangat berbahaya bagi biota dan manusia. Hasil uji (Tabel 7) menunjukkan konsentrasi raksa, cadmium, tembaga, timbal dan seng masih di bawah baku mutu yang menjadi rujukan pada studi ini. Hal tersebut dimungkinkan karena di sekitar muara Satui, tidak ada kegiatan yang secara signifikan menghasilkan limbah logam berat.

\section{Kualitas biologi perairan}

Sampling plankton pada studi ini dilakukan pada lokasi yang sama dengan sampling kualitas air. Hasil pengamatan plankton muara Satui disajikan pada Gambar 3. Hasil analisa plankton pada Gambar 3 menunjukkan Indeks keanekaragaman ShannonWiener dalam kisaran 1,68-1,82. Dari kategori tersebut dapat diketahui bahwa perairan di sekitar muara Satui mempunyai tingkat keanekaragaman sedang. Indeks keseragaman plankton pada muara Satui juga dapat dikategorikan sedang dengan kisaran nilai 0,56-0,63. Lebih lanjut, berdasar hasil analisa, kawasan muara Satui mempunyai nilai kisaran D' 0,20 - 0,27 yang artinya mempunyai perairan tersebut merupakan perairan dominasi rendah. Keanekaragaman dan dominansi plankton (tinggi, sedang dan rendah) dapat disebabkan oleh beberapa faktor yaitu umur suatu komunitas, tingkat kestabilan, tingkat suksesi, waktu, heterogenitas ruang, persaingan, pemangsaan,

Tabel 7. Hasil uji logam berat air di muara Satui

Table 7. The result of heavy metal at Satui estuary

\begin{tabular}{llllll}
\hline No & Parameter & Stasiun 1 & Stasiun 2 & Baku mutu & Keterangan \\
\hline 1 & Raksa & $<0,0006$ & - & 0,003 & $\mathrm{mg} / \mathrm{l}$ \\
2 & Cadmium & 0,005 & - & 0,01 & $\mathrm{mg} / \mathrm{l}$ \\
3 & Tembaga & 0,011 & - & 0,05 & $\mathrm{mg} / \mathrm{m}$ \\
4 & Timbal & 0,005 & - & 0,05 & $\mathrm{mg} / \mathrm{mg} / \mathrm{l}$ \\
5 & Seng & 0,012 & - & 0,1 & \\
\hline
\end{tabular}


stabilitas lingkungan, produktivitas dan penyesuaian diri setiap individu terhadap faktor-faktor fisik dan biologi di komunitas tersebut (Munthe et al, 2012). Dari Gambar 3 dapat disimpulkan perairan di sekitar muara Satui tercemar ringan berdasar nilai H' (1.68 1.82), akan tetapi dapat dikategorikan kategori perairan dengan kondisi baik dengan nilai D 0,20 - 0,27.

\section{Indeks Kualitas Air}

Analisa Indeks Kualitas Air/Water Quality Index (WQI, Brown et al., 1972) digunakan untuk menganalisa parameter fisika dan kimia yang mempunyai standar baku mutu lingkungan. Parameter minyak dan lemak serta Fenol tidak memperoleh hasil dalam analisa karena spektofotometer yang digunakan tidak dapat mendeteksi dengan konsentrasi di bawah $0,005 \mathrm{mg} / 1$. Hasil Analisa menunjukkan bahwa perairan muara Satui secara keseluruhan dalam kondisi yang baik dengan kisaran IKA tiap parameter pada kisaran 0,001 sampai 6.5 dengan total WQI berturut-turut 13.4 dan 0,17 untuk ST1 dan ST2 (Gambar 4). WQI di ST1 lebih tinggi karena adanya parameter logam berat yang diujikan.

Hasil studi menunjukkan secara fisika, kimia dan biologi muara Satui masih dalam kondisi yang baik untuk adanya kegiatan kepelabuhanan. Melihat potensi yang besar pada daerah Satui, baik dari pertambangan maupun pertanian dan lainnya, pengembangan kawasan pelabuhan terpadu untuk transportasi hasil kegiatan ekonomi di daerah tersebut perlu dilakukan untuk meningkatkan kesejahteraan masyarakat dengan tetap memperhatikan kelestarian kondisi lingkungan utamanya perairan. Studi ini dapat digunakan sebagai pedoman awal dalam pengembangan kawasan muara Satui sebagai Kawasan Pelabuhan Terpadu. Diharapkan, kondisi lingkungan perairan di muara Satui tetap terjaga seperti kondisi ketika studi ini dilakukan. Ke depannya diperlukan monitoring secara berkala dan konsep yang tepat dengan memperhatikan daya dukung lingkungan untuk pengembangan kawasan pelabuhan yang berkelanjutan.

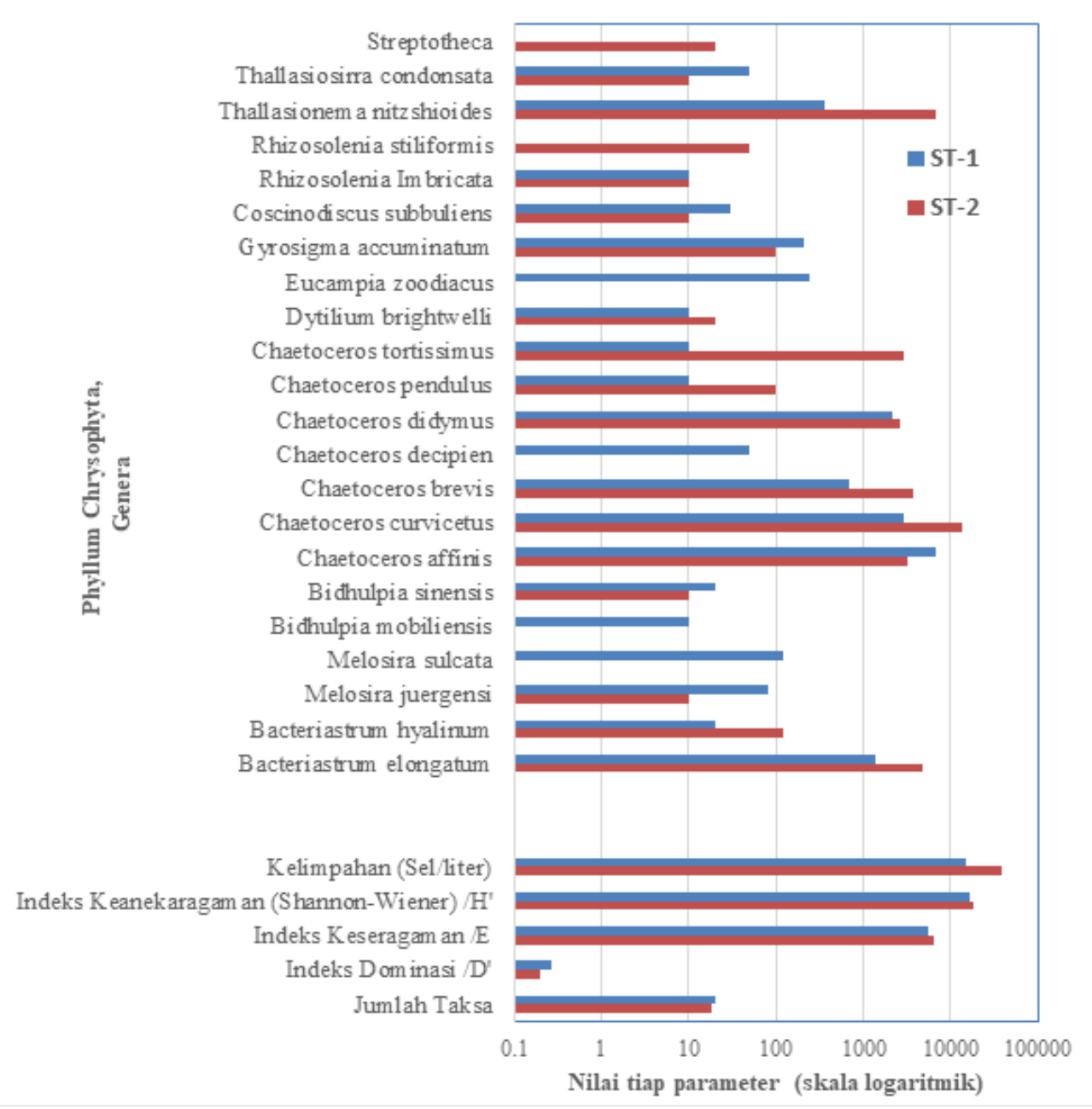

Gambar 3. Hasil analisa plankton.

Figure 3. Result of plankton analysis. 


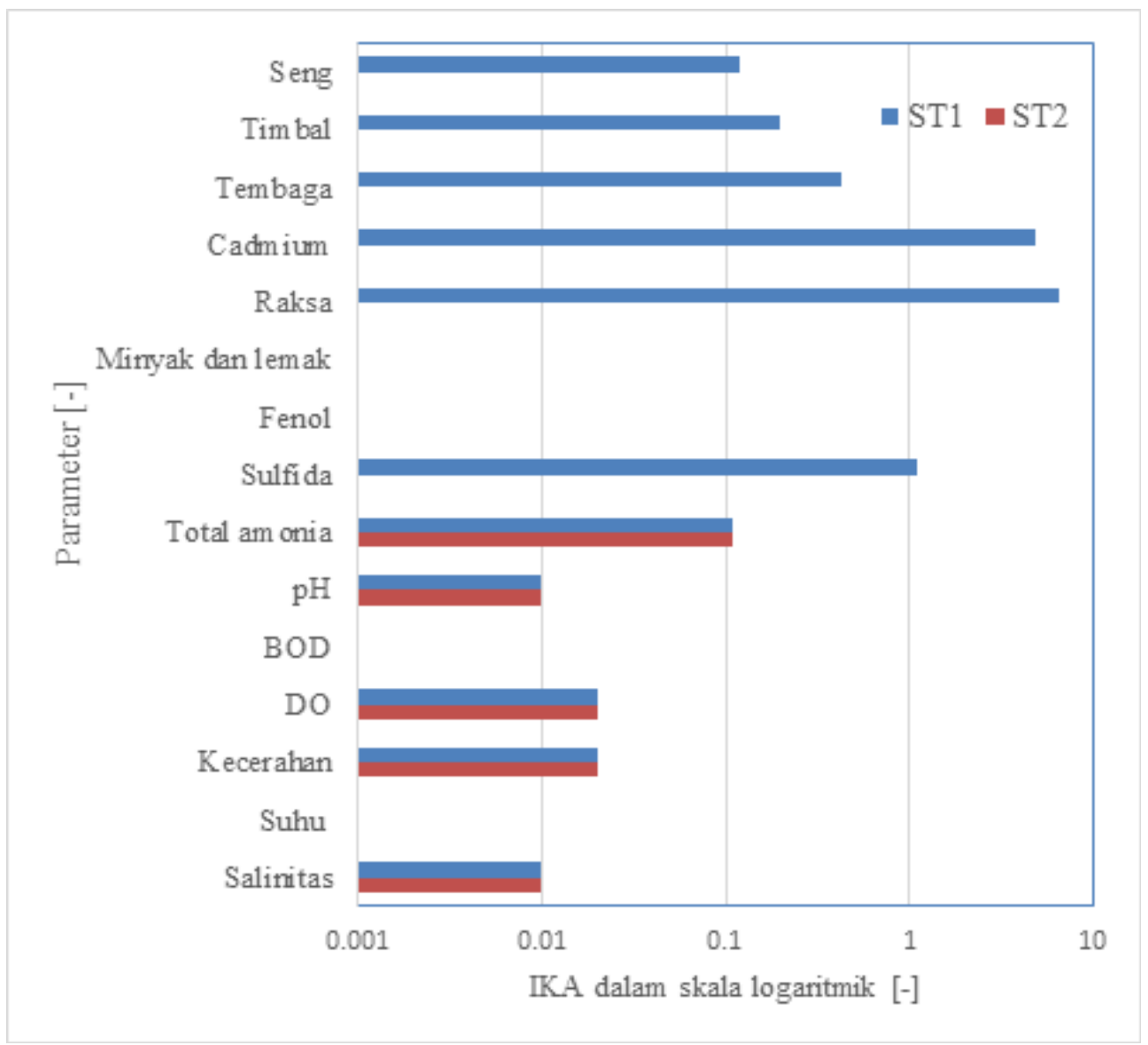

Gambar 4. Hasil perhitungan WQI untuk dua stasiun pengamatan di muara Satui.

Figure 4. WQI calculated for two observed points at Satui estuary.

\section{KESIMPULAN DAN SARAN}

Studi lapangan telah dilakukan di muara Satui, Kalimantan Selatan untuk mengetahui kualitas fisika, kimia biologi perairan di daerah tersebut. Sampling di lokasi studi menunjukkan walaupun kawasan muara Satui telah digunakan untuk kegiatan transportasi air, kondisi kualitas perairan tersebut masih di bawah baku mutu lingkungan yang ditetapkan berdasar standar baku mutu air laut di Keputusan Menteri Lingkungan Hidup No.51 tahun 2004. Hasil studi tersebut mengindikasikan perairan muara Satui masih dalam kondisi yang sangat bagus sehingga pengembangan Kawasan Pelabuhan sangat mungkin dilakukan.

\section{UCAPAN TERIMA KASIH}

Terima kasih kepada Pusat Penelitian dan Pengembangan Teknologi Kelautan (sekarang menjadi Pusat Riset Kelautan)-Badan Riset dan Sumber Daya KP - Kementerian Kelautan dan Perikanan Republik Indonesia, Laboratorium Kualitas Air Fakultas Perikanan dan Kelautan, Universitas Lambung
Mangkurat dan Laboratorium Pengujian Balai Pengembangan Teknologi dan Konstruksi Banjarmasin atas dukungan data dalam penelitian ini. Informasi terkait kontribusi penulis. Johan Risandi dan Vivi Yovita Indriasari adalah kontributor utama dalam studi ini.

\section{DAFTAR PUSTAKA}

Brown, R. M., Mc-Clelland, N. I., Deininger, R. A., \& O’Connor, M. F. (1972). A Water Quality Index Crashing the Psychological Barrier. In: Thomas W.A. (eds) Indicators of Environmental Quality. Environmental Science Research, vol 1. Springer, Boston, MA. https://doi.org/10,1007/978-14684-2856-8_1

Burchard, H. \& Baumert, H. (1998). The Formation of Estuarine Turbidity Maxima Due to Density Effects in the Salt Wedge. A Hydrodynamic Process Study. Journal of Physical Oceanography 28(2), 309-321. 
Darbra, R. M., Ronza, A., Stojanovic, T., Wooldridge, C., \& Casal, J. (2005). A Procedure for Identifying Significant Environmental Aspects in Sea Ports. Marine Pollution Bulletin, 50(8), 866-874.

Eljaiek-Urzola, M., Romero-Sierra, N., Segrera, L., Valdelamar, D., \& Quiñones-Bolaños, E. (2019). Oil and Grease as a Water Quality Index Parameter for the Conservation of Marine Biota. Water 11(4):856. 10,3390/w11040856.

Ellenberg, H. (1991). Biological Monitoring Signal From The Environment. Fried Vieweg and Jhon Verlago Sellcsharff Brounchweig. Germany.

Ignasiak-Szulc, A., Juščius, V., \& Bogatova, J. (2018). Economic Evaluation Model of Seaports' Performance Outlining Competitive Advantages and Disadvantages. Engineering Economics. 29(5). 10,5755/j01.ee.29.5.21363.

Jay, D. A., \& Musiak, J. D. (1994). Particle Trapping in Estuarine Tidal Flows. J. Geophys. Res., 99, 445-461

Jouanneau, S., Recoulesbc, L., Durand, M.J. Boukabacheb, A., Picot, V., Primault, Y. ., Lakel, A. Sengeline, M., Barillonf, B., \& Thouanda, G. (2014). Methods for Assessing Biochemical Oxygen Demand (BOD): A review. Water research, 49, 62-82.

Li, H. M., Zhanga, C. S., Hana, X. R., \& Shia, X. Y. (2014). Changes in concentrations of oxygen, dissolved nitrogen, phosphate, and silicate in the southern Yellow Sea, 1980-2012: Sources and seaward gradients. Estuarine, Coastal and Shelf Science, 163(Part A), 44-55.

Marganingrum, D., \& Noviardi, R. (2010). Pencemaran Air Dan Tanah Di Kawasan Pertambangan Batubara Di Pt. Berau Coal, Kalimantan Timur. Jurnal Riset Geologi dan Pertambangan, 20(1), 11-20.

Munthe, Y.V., \& Isnaini, R. A. (2012). Struktur Komunitas Dan Sebaran Fitoplankton Di Perairan Sungsang Sumatera Selatan. Maspari Journal, 4(1), 122-130.

Nontji. (2007). Laut Nusantara. Jakarta: Djambatan. $467 \mathrm{Hal}$.
Novotny V, H Olem. (1994). Water Quality: prevention, identification, and management of diffuse pollution. New York: van Nostrand Reinhold.

Nybakken, J. W. (1992). Biologi Laut Suatu Pendekatan Ekologis. Jakarta: PT. Gramedia Pustaka Utama.

Odum, E. P. (1993). Dasar - Dasar Ekologi. Gramedia. Jakarta. 697 hlm

Perwira, I. Y., \& Ulinuha, D. (2014). Phytoplankton Diversity as Ecological Indicator in Jimbaran Bay Waters. Journal of Environment, 1(1), 1827.

Prandle, D. (2004). Salt intrusion in partially mixed estuaries. Est. Coast. Shelf Sci. 59, 385-397

Protasov, A., Barinova, S., Novoselova, T., \& Sylaieva, A. (2019). The Aquatic Organisms Diversity, Community Structure, and Environmental Conditions. Diversity. 11(10), 190, 10,3390/ d11100190

Sa'diyah, H., Afiati, N., \& Purnomo, P. W. (2018). Kandungan Bahan Organik Sedimen dan Kadar H2S Air di Dalam dan di Luar Tegakan Mangrove Desa Bedono, Kabupaten Demak. Management of Aquatic Resources Journal (MAQUARES), 7(1), 78-85.

Saeni. (1997). Penentuan Tingkat Pencemaran Logam Berat dengan Analisis Rambut. Orasi Ilmiah. Fakultas Matematika dan Ilmu Pengetahuan Alam IPB, Bogor

Seda, F. (2006). Sumber Daya Alam Dan Pembangunan: Sebuah Perspektif Komparatif. Makara, Sosial Humaniora, 10(1), 33-48.

Şener, S., Sener, E., \& Davraz, Aysen. (2017). Evaluation of water quality using water quality index (WQI) method and GIS in Aksu River (SW-Turkey). Science of The Total Environment. 584-585, 131-144. 10,1016/j.scitotenv.2017.01.102.

Sivasubramanian, S., \& Namasivayamb, S. K. R. (2015). Phenol degradation studies using microbial consortium isolated from environmental sources. Journal of Environmental Chemical Engineering, 3(1), 243-252. 
Sugiyono. (2016). Metode Penelitian Kuantitatif Kualitatif dan R\&D. Edisi Kedua. Alfabeta, Bandung.

Tyagi, S., Sharma, B., \& Singh, P. (2013). Water Quality Assessment in Terms of Water Quality Index. American Journal of Water Resources. 1(3), 34-38. 10,12691/ajwr-1-3-3.

Wardhana, W. A. (2004). Dampak Pencemaran Lingkungan. edisi revisi. Penerbit ANDI. Yogyakarta

Wooldridge, C. F., McMullen, C., \& Howe, V. (1999). Environmental Management of Ports and Harbours-Implementation of Policy through Scientific Monitoring. Marine Policy, 23(4-5), 413-425. 
